\title{
ОСОБЛИВОСТІ АДДИКТИВНИХ І АФЕКТИВНИХ СТАНІВ, АСОЦІЙОВАНИХ З РОЗЛАДАМИ, ПОВ'ЯЗАНИМИ ІЗ ВЖИВАННЯМ АЛКОГОЛЮ, У ХВОРИХ З РІЗНИМ РІВНЕМ ПСИХОСОЦІАЛЬНОГО СТРЕСУ
}

\section{Харківська медична академія післядипломної освіти}

PЕзюмЕ. 4,2 \% українців мають проблеми, пов'язані зі вживанням алкоголю, що суттєво більше, ніж у більшості розвинених країн Європи. Це пов'язано зі значним підвищенням довготривалого стресового навантаження, в умовах якого живе зараз населення України, що породжує зростання рівня вживання алкоголю.

Мета дослідження - вивчення особливостей вираження та проявів аддиктивних і афективних станів, асоційованих з розладами, пов'язаними із вживанням алкоголю, у хворих з різним рівнем психосоціального стресу.

Матеріал і методи. Дослідження було здійснено на базі КНПХОР «Обласний наркологічний диспансер» протягом 2014-2018 рр., де за умови інформованої згоди з дотриманням принципів біоетики і деонтології було обстежено 312 чоловіків, хворих на алкогольну залежність (АЗ): 107 комбатантів, які мали досвід участі у бойових діях на Сході України як учасники Антитерористичної операції та Операції об'єднаних сил; 89 вимушено переміщених осіб із тимчасово окупованих районів Донецької та Луганської областей; 116 осіб - мешканців м. Харкова і Харківської області, які не були комбатантами або вимушено переміщеними особами. Дослідження містило використання клінічного, клініко-психопатологічного, психодіагностичного й статистичного методів.

Результати. Встановлено, що вираження і клінічна варіативність розладів, пов'язаних із вживанням алкоголю, асоційовані з вираженням психосоціального стресу, який випробовують хворі: зі збільшенням дезадаптивного стресового навантаження відбувається потяжчання клінічної симптоматики АЗ.

Аддиктивний статус хворих на АЗ демонструє напруженість за низкою аддиктивних об'єктів хімічного і нехімічного походження, вираження якої прямо або обернено асоційоване з вираженням АЗ та психосоціального стресу. Серед об'єктів хімічного походження (крім алкоголю), прямий кореляційний зв'язок встановлено для тютюну, психостимуляторів і кави/чаю, нехімічного походження - комп'ютерних ігор, а обернений зв'язок-для таких об'єктів нехімічної аддикції, як спорт і секс. Вираженість тютюнокуріння $\left(r_{s}=0,760\right)$ і схильності до надмірного захоплення комп'ютерними іграми $\left(r_{s}=0,703\right)$ більш тісно пов'язано з вираженням АЗ і психосоціального стресу, ніж аддиктивна напруженість за іншими аддиктивними об'єктами.

Вираження афективних феноменів у хворих на АЗ також виявилось конгруентним до динаміки вираження психосоціального стресу: зі збільшенням рівня психосоціального стресу спостерігали зростання тяжкості депресивних і тривожних проявів. Найбільш виражений прямий кореляційний зв'язок встановлено між тяжкістю АЗ та психосоціального стресу і психічною тривогою $\left(r_{s}=0,844\right)$ як складовою клінічної картини афективних розладів, притаманних обстеженим, хоча тіснота кореляційних зв'язків із вираженням як проявів патологічної тривоги, так і депресії була на рівні високої в обох випадках ( $r_{\mathrm{s}}=0,797$ і $r_{\mathrm{s}}=0,731$ відповідно).

Висновки. Перспективою подальших досліджень $\epsilon$ створення системи таргетно персоніфікованих лікувальнореабілітаційних і профілактичних заходів, диференційованих залежно від рівня патологічного стресового навантаження, випробовуваного пацієнтами, і впровадження її в існуючу комплексну систему надання спеціалізованої медичної допомоги хворим на АЗ.

КЛЮчОВІ СлОВА: алкогольна залежність; психосоціальний стрес; аддиктивний статус; афективні розлади; депресія; тривога.

Вступ. За даними світового дослідження 4,2 \% українців мають проблеми, пов'язані зі вживанням алкоголю [1]. Це суттєво більше, ніж у більшості розвинених країн Європи, i, на думку фахівців, цьому становищу $\epsilon$ декілька пояснень. Поперше, це доступність алкогольних виробів через відносно низьку ціну та відсутність обмежень при покупці [2], по-друге, це суспільно-економічні трансформації, що відбуваються внаслідок гібридної війни проти України, через які значна кількість населення зустрічається з економічними труднощами, тоді як науково доведеним $\epsilon$ факт взаємозв'язку між бідністю і зловживанням алкоголем [3], по-третє, це значна кількість соціально зумовлених стресогенних чинників, наслідком чого $\epsilon$ значне підвищення довготривалого стресового навантаження, в умовах якого живе населення України, що породжує зростання рівня вживання алкоголю, яке виникає як несприятливий механізм компенсації нервово-психічної напруги та варіант хронізації різноманітних постстресових розладів, доходячи іноді до їх клінічно окресленої коморбідності $[4,5]$.

Враховуючи системний взаємовплив двох зазначених феноменів, підходи до лікування розладів, пов'язаних із вживанням алкоголю, із коморбідними постстресовими афективними та/або аддиктивними станами, мають базуватися на біопсихосоціальних засадах, а існуючі терапевтичні й реабілітаційні стратегії повинні бути суттєво мо- 
Огляди літератури, оригінальні дослідження, погляд на проблему, ювілеї

дифіковані з урахуванням вектора дії стресу на формування й перебіг алкогольної залежності (АЗ).

Мета дослідження - вивчення особливостей вираження та проявів аддиктивних і афективних станів, асоційованих з розладами, пов'язаними із вживанням алкоголю, у хворих із різним рівнем психосоціального стресу для розуміння шляхів модифікації існуючих терапевтичних і реабілітаційних стратегій з урахуванням обтяжуючої дії стресу та коморбідних феноменів на їх формування й перебіг.

Матеріал і методи дослідження. На базі КНПХОР «Обласний наркологічний диспансер» протягом 2014-2018 рр. за умови інформованої згоди з дотриманням принципів біоетики і деонтології було обстежено 312 чоловіків, хворих на АЗ: 107 комбатантів, які мали досвід участі у бойових діях на Сході України як учасники Антитерористичної операції та Операції об'єднаних сил; 89 вимушено переміщених осіб із тимчасово окупованих районів Донецької та Луганської областей; 116 осіб - мешканців м. Харкова і Харківської області, які не були комбатантами або вимушено переміщеними особами.

Дослідження містило використання клінічного, клініко-психопатологічного й психодіагностичного методів. Діагностику АЗ здійснювали за допомогою клініко-психопатологічного методу, що був доповнений використанням, окрім клінічного структурованого інтерв'ю згідно з діагностичними критеріями MKX-10 [6], психодіагностичним дослідженням з використанням тесту AUDIT (для виявлення розладів, пов'язаних зі зловживанням алкоголем та визначення ступеня небезпечності його вживання) [7] і шкали оцінки стану відміни алкоголю SADQ-C [8]. Вимір тяжкості психосоціального стресу здійснювали за однойменною шкалою Л. Рідера [9] й шкалою психологічного стресу Lemyr-Tessier-Fillion в адаптації Н. Є. Водопьянової (PSM-25) [10]. Аддиктивний статус досліджували за допомогою батареї AUDIT-подібних тестів, розроблених колективом авторів під керівництвом І. В. Лінського [11], а також «Тесту для виявлення розладів, пов' язаних з захопленістю спортом (фітнесом) SPORT-UDIT (версія «самозвіт») для непрофесіоналів» [12]. Оцінку стану афективної сфери проводили з використанням шкал депресії та тривоги М. Гамільтона (Hamilton Rating Scale for DepressionHRDS та Hamilton Anxiety Rating Scale - HARS) [13]. Статистико-математичний аналіз включав формування описової статистики та аналіз розбіжностей з використанням непараметричних методів: тесту Манна-Уїтні та точного критерію Фішера.

Результати й обговорення. За критерієм тяжкості переживання психосоціального стресу (за шкалою Л. Рідера) обстежені були розподілені на три групи за критерієм тяжкості переживання психосоціального стресу: з низьким рівнем - 35 осіб (показник за шкалою до 0,99 балів), з помірним рівнем - 84 особи (показник від 1,00 до 1,99 балів) та з високим рівнем - 193 особи (показник понад 2,00 бали).

Відносно низький рівень психосоціального стресу зустрічався у 2 (1,9\%) комбатантів (група К1), 9 (10,1%) переселенців (група П1) і 24 (20,7%) місцевих мешканців (група М1) (середній показ-

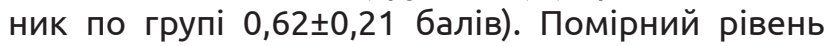
стресу було виявлено у $29(27,1 \%)$ комбатантів (група К2), 22 (24,7 \%) переселенців (група П2) й 33 (28,4 \%) місцевих мешканців (група М2) (середній показник $(1,39 \pm 0,30)$ бала). Тяжкий рівень стресового навантаження встановлено у 76 (71,0\%) комбатантів (група К3), 58 (65,2 \%) переселенців (група П3) та 59 (50,9 \%) міських мешканців (група М3) (середній показник $(2,47 \pm 0,38)$ бала). Розбіжності при порівнянні середнього вираження психосоціального стресу в даних групах були статистично значущими $(p<0,01)$.

Середні показники вираження психосоціального стресу в осіб різних соціальних груп склали: серед комбатантів - $(2,24 \pm 0,63)$ бала; переселенців - $(2,03 \pm 0,72)$ бала; місцевих мешканців $(1,68 \pm 0,78)$ бала (розбіжності були статистично значущі при порівнянні груп комбатантів і місцевих та переселенців і місцевих, $\mathrm{p}<0,01)$.

Схожа тенденція була виявлена стосовно вразливості до психологічного стресу (методика PSM-25): у комбатантів середнє його вираження становило $(151,62 \pm 25,82)$ бала, у переселенців $(143,56 \pm 31,20)$ бала, місцевих мешканців $(131,09 \pm 36,04)$ бала (розбіжності при порівнянні комбатантів і переселенців p>0,05, комбатантів і місцевих $p<0,01$, переселенців і місцевих $p<0,01)$.

Середній показник у групі осіб з легким рівнем реагування на психосоціальний стрес був $(72,46 \pm 9,37)$ бала, помірним реагуванням $(123,30 \pm 19,97)$ бала, тяжким - $(162,25 \pm 9,43)$ бала (розбіжності статистично значущі при порівнянні всіх груп між собою, $p<0,01)$.

За клінічним вираженням і змістовним наповненням симптомів $A 3$, оцінених із застосуванням дослідницьких діагностичних критеріїв MKX-10, у хворих різних соціальних груп були виявлені деякі розбіжності, а саме [14]:

- сильне бажання або непереборне прагнення вживати алкоголь («спрага»), а також психологічна або соматична шкода були наявні в усіх обстежених (при порівнянні комбатантів з переселенцями p>0,05; комбатантів з місцевими $p>0,05$, переселенців з місцевими р>0,05);

- порушена здатність контролювати вживання алкоголю («втрата контролю») та фізіологічна, 
Огляди літератури, оригінальні дослідження, погляд на проблему, ювілеї

поведінкова або психологічна толерантність були виявлені в усіх комбатантів і переселенців та у 97,4 і 95,7 \% місцевих жителів відповідно ( $p>0,05$, $\mathrm{p}<0,05$ та $\mathrm{p}<0,05)$;

- уживання алкоголю з метою зм'якшення або запобігання симптомам абстиненції було виявлено у 72,9\% комбатантів, 69,7 \% переселенців і 57,8 \% місцевих ( $>>0,05, p<0,05, p>0,05)$;

- стан абстиненції - відповідно, у 79,4, 71,9 та $62,1 \%(p<0,01, p<0,01, p<0,01)$;

- звуження асортименту спиртних напоїв, які вживаються - у 68,2, 64,0 та 50,9 \% відповідно $(p>0,05, p<0,05, p<0,01)$;

- прогресивне звуження спектра альтернативних задоволень, форм поводження або інтересів - відповідно, у 41,1, 36,0 та 23,3 \% ( $p>0,05$, $p<0,05, p<0,01)$;

- постійне вживання алкоголю, незважаючи на очевидні докази його шкідливих наслідків - у 48,6, $43,8$ та 41,4 \% відповідно ( $p>0,05, p>0,05, p>0,05)$.

Натомість суттєво більш виражені відмінності були виявлені під час аналізу клінічної симптоматики АЗ з урахуванням рівня психосоціального стресу, що дозволило вважати цей фактор провідним у визначенні поширеності тих або інших симптомів АЗ [14]:

- сильне бажання або непереборне прагнення вживати алкоголь («спрага») та психологічна або соматична шкода були виявлені в усіх обстежених (p>0,05);

- порушена здатність контролювати вживання алкоголю («втрата контролю») - у 91,4 \% хворих із легким рівнем стресового реагування і у всіх пацієнтів із помірним і високим стресовим навантаженням ( $<<0,05, p<0,01, p>0,05)$;

- толерантність (фізіологічна, поведінкова або психологічна) - у 85,7 \% хворих із легким стресом і у всіх обстежених із помірним та тяжким рівнями переживанням стресу ( $p<0,01, p<0,01, p>0,05)$;

- уживання алкоголю з метою пом'якшення або запобігання симптомам абстиненції не виявлено в осіб із легким рівнем і відзначено у 20,2 \% пацієнтів із помірним та у 98,4 \% - із тяжким стре$\operatorname{com}(p<0,01, p<0,01, p<0,01)$;

- стан абстиненції не виявлений у хворих із легким рівнем переживання стресу, натомість, виявлено у 33,0 \% обстежених із помірним та у всіх - із тяжким рівнем стресового навантаження $(p<0,01, p<0,01, p<0,01)$;

- звуження асортименту спиртних напоїв, які вживаються, не виявлено у хворих з легкою та помірною формами стресового реагування, і було наявне у 97,9 \% пацієнтів із високим рівнем стресової дезадаптації ( $p>0,05, p<0,01, p<0,01)$;

- прогресивне звуження спектра альтернативних задоволень, форм поводження або інте- ресів не виявлено в обстежених із легким та помірним рівнями психосоціального стресу, і було наявне у 53,4 \% хворих із високим рівнем стресового навантаження ( $p>0,05, p<0,01, p<0,01)$;

- постійне вживання алкоголю, незважаючи на очевидні докази його шкідливих наслідків, було виявлено у 2,9 \% хворих з легким, у 38,1\% з помірним і у 54,9 \% - із високим рівнем випробуваного стресу $(p<0,01, p<0,01, p<0,05)$.

Вираження клінічних проявів A3 (за AUDIT) серед комбатантів становило $(30,43 \pm 7,31)$ бала, переселенців - $(28,60 \pm 7,78)$ бала, місцевих мешканців - $(25,43 \pm 8,19)$ бала (розбіжності статистично значущі при порівнянні комбатантів і місцевих p<0,01, переселенців і місцевих $p<0,01)$.

Серед осіб із легким стресом середній показник за AUDIT склав $(15,17 \pm 2,3)$ бала, з помірним реагуванням на стрес - $(21,53 \pm 1,99)$ бала, тяжким $(31,51 \pm 6,35)$ бала (розбіжності статистично значущі при порівнянні всіх груп між собою р<0,01).

Розбіжності за вираженням та клінічною варіативністю стану відміни (шкала SADQ-C) також мали суттєві відмінності у розрізі вираження психосоціального стресу: середній показник у хворих з легким рівнем психосоціального стресу склав $(9,14 \pm 6,03)$ бала, з помірним рівнем - $(36,89 \pm 5,40)$ бала, з високим рівнем - $(46,65 \pm 7,62)$ бала (розбіжності статистично значущі при порівнянні всіх груп p<0,01), тоді як між пацієнтами різних соціальних груп розбіжності здебільшого не мали статистичної значущості (комбатанти - $(43,48 \pm 9,17)$ бала, переселенці - $(41,04 \pm 13,18)$ бала, p>0,05; місцеві $(35,49 \pm 16,02)$ бала, $p<0,01)$.

Оцінка напруженості аддиктивного статусу обстежених за іншими об'єктами хімічного та нехімічного походження, довела наявність більших розбіжностей між хворими з різним рівнем психосоціального стресу, ніж між особами різних соціальних груп (табл. 1-4).

Треба зазначити, що обраний нами психодіагностичний інструментарій, а саме система AUDITподібних тестів, дозволяє в єдиному вимірювальному масштабі оцінити тяжкість розладів, пов' язаних із різними об'єктами вживання: з наркотиками, тютюном, кавою або чаєм, їжею, а також із сексуальною активністю, з трудовою діяльністю, 3 переглядом телепередач, з використанням Інтернету, з азартними іграми (карти, рулетка і т. ін.), з іграми на телеприставці і комп' ютерними іграми, з шопінгом та читанням, а також дослідити взаємні впливи зазначених розладів один на одного. За висловлюванням авторів методики, у випадку визначення відношення до видів аддикції нехімічного походження, термін «вживання» використовується з певною часткою умовності, оскільки мовні традиції не передбачають поєднань на 
Огляди літератури, оригінальні дослідження, погляд на проблему, ювілеї

кшталт "вживання» стосовно гри в карти або «вживання» телепередач, але єдиний підхід до вимірювання пристрастей і залежностей різного походження, реалізований в концепції аддиктивного статусу, вимагає єдності термінології [15].

Отже, у хворих на АЗ із легким рівнем психосоціального стресу, незалежно від належності до соціальної групи, встановлено схильність до вживання зі шкідливими наслідками таких аддиктивних об'єктів нехімічного походження, як спорт і секс. Пацієнтам із тяжким стресовим навантаженням були притаманні схильності на рівні вживання зі шкідливими наслідками як за об'єктами хімічного походження (кава/чай та психостимулятори), так і нехімічного походження (комп'ютерні ігри). Загальною закономірністю для усіх хворих на АЗ із помірним і тяжким рівнями психосоціального стресу була також наявність клінічно окресленої тютюнової залежності (переселенці та місцеві мешканці з легким рівнем стресу продемонстрували небезпечний рівень вживання тютюну).

Разом з тим, серед особливостей аддиктивної реалізації на рівні соціальних груп, що мали підтвердження за достовірністю розбіжностей 3 іншими групами, виділено такі:

- для комбатантів - за таким аддиктивним об'єктом, як комп'ютерні ігри: висока напруже- ність при легкому рівні стресу зменшувалася із збільшенням його тяжкості, проте при подальшому зростанні тяжкості стресу знову зростала, тоді як в інших осіб із АЗ спостерігали тенденцію до збільшення аддиктивної напруженості паралельно зі зростанням інтенсивності стресу;

- для місцевих мешканців-за таким об'єктом, як телебачення: схильність до його надмірного перегляду зростала серед них зі збільшенням вираження психосоціального стресу, доходячи в осіб із тяжким стресовим навантаженням до небезпечного рівня вживання, тоді як серед комбатантів і переселенців зафіксовано протилежну закономірність: будучи на початку незначною, вона ще більше зменшувалася зі збільшенням тяжкості стресу.

Таким чином, суттєві розбіжності в аддиктивному статусі комбатантів, переселенців і місцевих мешканців, хворих на АЗ, встановлені за аддиктивними об'єктами нехімічного походження, а саме комп'ютерними іграми та переглядом телебачення; разом з тим, при порівнянні аддиктивного статусу осіб із різним рівнем психосоціального стресу виявлено суттєві розбіжності за об'єктами як хімічного (тютюн, психостимулятори, кава/чай), так і нехімічного походження (спорт, секс, комп'ютерні ігри).

Таблиця 1. Середні показники напруженості аддиктивного статусу за різними об'єктами у комбатантів із АЗ та різним вираженням психосоціального стресу

\begin{tabular}{|c|c|c|c|c|c|c|}
\hline \multirow{2}{*}{ Аддиктивний об'єкт } & \multicolumn{3}{|c|}{ Групи } & \multicolumn{3}{|c|}{$\mathrm{p}$} \\
\hline & K1 & $\mathrm{K} 2$ & K3 & K1 vs K2 & K1 vs K3 & $\mathrm{K} 2$ vs K3 \\
\hline Спорт & $14,50 \pm 6,36$ & $9,48 \pm 6,34$ & $6,26 \pm 6,85$ & $<0,05$ & $<0,05$ & $<0,05$ \\
\hline Їжа & $6,00 \pm 1,41$ & $12,10 \pm 2,76$ & $13,36 \pm 2,41$ & $<0,05$ & $<0,05$ & $<0,05$ \\
\hline Секс & $13,50 \pm 4,95$ & $9,21 \pm 10,35$ & $7,16 \pm 11,17$ & $<0,05$ & $<0,05$ & $<0,05$ \\
\hline Робота & $8,50 \pm 0,71$ & $9,59 \pm 9,32$ & $15,08 \pm 10,41$ & $>0,05$ & $<0,05$ & $<0,05$ \\
\hline Телебачення & $10,50 \pm 0,71$ & $9,72 \pm 10,08$ & $7,26 \pm 11,04$ & $<0,05$ & $<0,05$ & $<0,05$ \\
\hline Інтернет & $11,50 \pm 0,71$ & $10,66 \pm 8,91$ & $8,71 \pm 9,87$ & $<0,05$ & $<0,05$ & $<0,05$ \\
\hline Азартні ігри & $5,50 \pm 2,12$ & $7,62 \pm 8,42$ & $9,43 \pm 11,72$ & $>0,05$ & $>0,05$ & $>0,05$ \\
\hline Комп'ютерні ігри & $16,00 \pm 1,41$ & $12,66 \pm 2,02$ & $14,67 \pm 4,21$ & $<0,05$ & $>0,05$ & $<0,05$ \\
\hline Шопінг & $4,50 \pm 0,71$ & $5,41 \pm 4,98$ & $6,17 \pm 7,27$ & $>0,05$ & $>0,05$ & $>0,05$ \\
\hline Читання & $1,50 \pm 0,71$ & $2,97 \pm 2,23$ & $5,36 \pm 3,52$ & $>0,05$ & $>0,05$ & $>0,05$ \\
\hline Куріння тютюну & $20,00 \pm 1,41$ & $24,21 \pm 1,80$ & $26,82 \pm 9,36$ & $<0,05$ & $<0,05$ & $<0,05$ \\
\hline Кава та чай & $7,50 \pm 0,71$ & $11,34 \pm 3,18$ & $13,82 \pm 4,12$ & $<0,05$ & $<0,05$ & $<0,05$ \\
\hline Канабіноїди & $5,00 \pm 1,41$ & $5,38 \pm 3,70$ & $6,11 \pm 6,18$ & $>0,05$ & $>0,05$ & $>0,05$ \\
\hline $\begin{array}{l}\text { Леткі органічні } \\
\text { сполуки }\end{array}$ & $0,00 \pm 0,00$ & $0,00 \pm 0,00$ & $0,00 \pm 0,00$ & $>0,05$ & $>0,05$ & $>0,05$ \\
\hline $\begin{array}{l}\text { Седативні та } \\
\text { снодійні засоби }\end{array}$ & $6,50 \pm 3,54$ & $7,55 \pm 5,25$ & $9,47 \pm 5,72$ & $>0,05$ & $<0,05$ & $<0,05$ \\
\hline Психостимулятори & $7,00 \pm 0,00$ & $8,00 \pm 3,27$ & $11,00 \pm 6,85$ & $>0,05$ & $>0,05$ & $>0,05$ \\
\hline Опіати & $0,00 \pm 0,00$ & $0,00 \pm 0,00$ & $0,00 \pm 0,00$ & $>0,05$ & $>0,05$ & $>0,05$ \\
\hline Психоделічні засоби & $0,00 \pm 0,00$ & $0,00 \pm 0,00$ & $0,00 \pm 0,00$ & $>0,05$ & $>0,05$ & $>0,05$ \\
\hline
\end{tabular}

Результати дослідження показників за AUDITподібними тестами у переселенців із АЗ та різним вираженням стресу наведено у таблиці 2.
У таблиці 3 наведено середні показники за AUDIT-подібними тестами у місцевих мешканців із АЗ та різним вираженням стресу. 
Огляди літератури, оригінальні дослідження, погляд на проблему, ювілеї

Таблиця 2. Середні показники напруженості аддиктивного статусу за різними об'єктами у переселенців із АЗ та різним вираженням психосоціального стресу

\begin{tabular}{|c|c|c|c|c|c|c|}
\hline \multirow{2}{*}{ Аддиктивний об'єкт } & \multicolumn{3}{|c|}{ Групи } & \multicolumn{3}{|c|}{$p$} \\
\hline & $\Pi 1$ & $\Pi 2$ & $\Pi 3$ & $\Pi 1$ vs $\Pi 2$ & $\Pi 1 \mathrm{vs} \Pi 3$ & $\Pi 2$ vs $\Pi 3$ \\
\hline Спорт & $14,78 \pm 4,15$ & $9,27 \pm 7,34$ & $6,29 \pm 6,02$ & $<0,05$ & $<0,01$ & $>0,05$ \\
\hline Їжа & $5,56 \pm 1,88$ & $8,32 \pm 2,48$ & $9,84 \pm 2,50$ & $<0,05$ & $<0,01$ & $<0,05$ \\
\hline Секс & $13,56 \pm 14,75$ & $8,05 \pm 15,16$ & $7,12 \pm 7,60$ & $<0,05$ & $<0,05$ & $<0,05$ \\
\hline Робота & $8,89 \pm 7,34$ & $10,14 \pm 8,74$ & $13,69 \pm 11,21$ & $>0,05$ & $>0,05$ & $>0,05$ \\
\hline Телебачення & $14,11 \pm 14,74$ & $8,18 \pm 15,19$ & $7,71 \pm 7,51$ & $<0,05$ & $<0,05$ & $<0,05$ \\
\hline Інтернет & $14,67 \pm 13,12$ & $9,23 \pm 13,64$ & $9,31 \pm 6,75$ & $<0,05$ & $<0,05$ & $<0,05$ \\
\hline Азартні ігри & $5,33 \pm 4,33$ & $7,09 \pm 8,87$ & $9,12 \pm 8,24$ & $>0,05$ & $>0,05$ & $>0,05$ \\
\hline Комп'ютерні ігри & $9,89 \pm 0,93$ & $11,45 \pm 1,92$ & $12,98 \pm 5,81$ & $<0,05$ & $<0,01$ & $<0,05$ \\
\hline Шопінг & $3,56 \pm 2,35$ & $4,95 \pm 4,97$ & $5,12 \pm 5,16$ & $>0,05$ & $>0,05$ & $>0,05$ \\
\hline Читання & $1,78 \pm 1,79$ & $3,73 \pm 2,78$ & $5,48 \pm 3,88$ & $>0,05$ & $<0,01$ & $<0,05$ \\
\hline Куріння тютюну & $19,33 \pm 1,87$ & $23,50 \pm 1,74$ & $26,47 \pm 15,94$ & $<0,01$ & $<0,05$ & $<0,01$ \\
\hline Кава та чай & $7,00 \pm 1,66$ & $10,14 \pm 5,37$ & $13,36 \pm 7,02$ & $<0,05$ & 0,001 & $<0,05$ \\
\hline Канабіноїди & $4,22 \pm 1,72$ & $4,86 \pm 3,92$ & $5,84 \pm 3,77$ & $>0,05$ & $>0,05$ & $>0,05$ \\
\hline $\begin{array}{l}\text { Леткі органічні } \\
\text { сполуки }\end{array}$ & $0,00 \pm 0,00$ & $0,00 \pm 0,00$ & $0,00 \pm 0,00$ & $>0,05$ & $>0,05$ & $>0,05$ \\
\hline $\begin{array}{l}\text { Седативні та } \\
\text { снодійні засоби }\end{array}$ & $6,56 \pm 1,81$ & $8,50 \pm 4,68$ & $9,66 \pm 4,93$ & $<0,05$ & $<0,01$ & $>0,05$ \\
\hline Психостимулятори & $8,22 \pm 2,59$ & $8,59 \pm 3,96$ & $10,40 \pm 7,47$ & $>0,05$ & $>0,05$ & $>0,05$ \\
\hline Опіати & $0,00 \pm 0,00$ & $0,00 \pm 0,00$ & $0,00 \pm 0,00$ & $>0,05$ & $>0,05$ & $>0,05$ \\
\hline Психоделічні засоби & $0,00 \pm 0,00$ & $0,00 \pm 0,00$ & $0,00 \pm 0,00$ & $>0,05$ & $>0,05$ & $>0,05$ \\
\hline
\end{tabular}

Таблиця 3. Середні показники напруженості аддиктивного статусу за різними об'єктами у місцевих мешканців із АЗ та різним рівнем психосоціального стресу

\begin{tabular}{|c|c|c|c|c|c|c|}
\hline \multirow{2}{*}{ Аддиктивний об'єкт } & \multicolumn{3}{|c|}{ Групи } & \multicolumn{3}{|c|}{$\mathrm{p}$} \\
\hline & M1 & M2 & M3 & M1 vs $M 2$ & M1 vs M3 & M2 vs $M 3$ \\
\hline Спорт & $12,29 \pm 5,32$ & $8,06 \pm 6,75$ & $4,93 \pm 5,83$ & $<0,05$ & $<0,01$ & $<0,05$ \\
\hline Їжа & $6,08 \pm 2,38$ & $7,61 \pm 2,44$ & $8,66 \pm 1,86$ & $<0,05$ & $<0,01$ & $<0,05$ \\
\hline Секс & $11,58 \pm 12,80$ & $9,42 \pm 14,23$ & $7,25 \pm 5,25$ & $<0,05$ & $<0,05$ & $<0,05$ \\
\hline Робота & $10,17 \pm 5,88$ & $10,82 \pm 8,87$ & $11,47 \pm 9,36$ & $>0,05$ & $>0,05$ & $>0,05$ \\
\hline Телебачення & $11,08 \pm 6,49$ & $14,36 \pm 10,44$ & $16,63 \pm 11,41$ & $>0,05$ & $<0,05$ & $>0,05$ \\
\hline Інтернет & $6,54 \pm 2,81$ & $10,15 \pm 7,31$ & $12,83 \pm 7,83$ & $<0,05$ & $<0,01$ & $<0,05$ \\
\hline Азартні ігри & $5,04 \pm 7,49$ & $6,91 \pm 8,86$ & $8,92 \pm 10,28$ & $>0,05$ & $>0,05$ & $>0,05$ \\
\hline Комп'ютерні ігри & $9,88 \pm 0,80$ & $9,79 \pm 5,45$ & $10,59 \pm 6,40$ & $<0,05$ & $<0,05$ & $<0,05$ \\
\hline Шопінг & $4,88 \pm 5,24$ & $4,70 \pm 4,84$ & $6,76 \pm 6,88$ & $>0,05$ & $>0,05$ & $>0,05$ \\
\hline Читання & $2,17 \pm 2,39$ & $4,00 \pm 3,98$ & $7,07 \pm 5,60$ & $>0,05$ & $<0,01$ & $<0,01$ \\
\hline Куріння тютюну & $17,42 \pm 5,79$ & $23,36 \pm 4,49$ & $24,10 \pm 16,20$ & $<0,01$ & $<0,01$ & $<0,01$ \\
\hline Кава та чай & $6,54 \pm 2,38$ & $7,85 \pm 5,36$ & $10,54 \pm 9,48$ & $<0,05$ & $<0,05$ & $<0,05$ \\
\hline Канабіноїди & $4,96 \pm 3,56$ & $4,79 \pm 4,08$ & $6,34 \pm 5,26$ & $>0,05$ & $>0,05$ & $>0,05$ \\
\hline $\begin{array}{l}\text { Леткі органічні } \\
\text { сполуки }\end{array}$ & $0,00 \pm 0,00$ & $0,00 \pm 0,00$ & $0,00 \pm 0,00$ & $>0,05$ & $>0,05$ & $>0,05$ \\
\hline $\begin{array}{l}\text { Седативні та } \\
\text { снодійні засоби }\end{array}$ & $3,79 \pm 1,47$ & $4,67 \pm 5,54$ & $5,15 \pm 3,92$ & $>0,05$ & $>0,05$ & $>0,05$ \\
\hline Психостимулятори & $8,29 \pm 2,91$ & $8,85 \pm 5,46$ & $11,56 \pm 4,78$ & $>0,05$ & $<0,01$ & $<0,01$ \\
\hline Опіати & $0,00 \pm 0,00$ & $0,00 \pm 0,00$ & $0,00 \pm 0,00$ & $>0,05$ & $>0,05$ & $>0,05$ \\
\hline Психоделічні засоби & $0,00 \pm 0,00$ & $0,00 \pm 0,00$ & $0,00 \pm 0,00$ & $>0,05$ & $>0,05$ & $>0,05$ \\
\hline
\end{tabular}

Результати аналізу статистичної значущості розбіжностей при порівнянні різних груп хворих на АЗ за різними аддиктивними об'єктами наведено у таблиці 4. 
Огляди літератури, оригінальні дослідження, погляд на проблему, ювілеї

Таблиця 4. Рівні статистичної значущості розбіжностей при порівнянні напруженості аддиктивного статусу у групах досліджених хворих із АЗ за різними аддиктивними об'єктами

\begin{tabular}{|l|c|c|c|c|c|c|c|c|c|}
\hline \multicolumn{1}{|c|}{$\begin{array}{c}\text { Аддиктивні } \\
\text { фактори }\end{array}$} & \multicolumn{7}{|c|}{ Рівень статистичної значущості розбіжностей при порівнянні груп } \\
\cline { 2 - 11 } & K1 vs П1 & K1 vs M1 & П1 vs M1 & K1 vs П1 & K1 vs M1 & П1 vs M1 & K1 vs П1 & K1 vs M1 & П1 vs M1 \\
\hline Спорт & $>0,05$ & $>0,05$ & $>0,05$ & $>0,05$ & $>0,05$ & $>0,05$ & $>0,05$ & $>0,05$ & $>0,05$ \\
\hline Ïжа & $>0,05$ & $>0,05$ & $>0,05$ & $<0,01$ & $<0,01$ & $>0,05$ & $<0,01$ & $<0,01$ & $<0,01$ \\
\hline Секс & $>0,05$ & $>0,05$ & $>0,05$ & $<0,01$ & $<0,05$ & $>0,05$ & $<0,01$ & $<0,01$ & $>0,05$ \\
\hline Робота & $>0,05$ & $>0,05$ & $>0,05$ & $>0,05$ & $>0,05$ & $>0,05$ & $>0,05$ & $<0,01$ & $>0,05$ \\
\hline Телебачення & $>0,05$ & $>0,05$ & $>0,05$ & $<0,01$ & $<0,01$ & $<0,01$ & $<0,01$ & $<0,01$ & $<0,01$ \\
\hline Інтернет & $>0,05$ & $<0,05$ & $>0,05$ & $<0,01$ & $>0,05$ & $<0,01$ & $<0,05$ & $<0,01$ & $<0,01$ \\
\hline Азартні ігри & $>0,05$ & $>0,05$ & $>0,05$ & $>0,05$ & $>0,05$ & $>0,05$ & $>0,05$ & $>0,05$ & $>0,05$ \\
\hline Комп'ютерні ігри & $<0,05$ & $<0,05$ & $>0,05$ & $<0,05$ & $>0,05$ & $>0,05$ & $>0,05$ & $<0,01$ & $>0,05$ \\
\hline Шопінг & $>0,05$ & $>0,05$ & $>0,05$ & $>0,05$ & $>0,05$ & $>0,05$ & $>0,05$ & $>0,05$ & $>0,05$ \\
\hline Читання & $>0,05$ & $>0,05$ & $>0,05$ & $>0,05$ & $>0,05$ & $>0,05$ & $>0,05$ & $>0,05$ & $>0,05$ \\
\hline Куріння тютюну & $>0,05$ & $>0,05$ & $>0,05$ & $>0,05$ & $>0,05$ & $>0,05$ & $<0,01$ & $<0,05$ & $>0,05$ \\
\hline Кава та чай & $>0,05$ & $>0,05$ & $>0,05$ & $>0,05$ & $<0,05$ & $<0,05$ & $>0,05$ & $<0,05$ & $<0,05$ \\
\hline Канабіноїди & $>0,05$ & $>0,05$ & $>0,05$ & $>0,05$ & $>0,05$ & $>0,05$ & $>0,05$ & $>0,05$ & $>0,05$ \\
\hline $\begin{array}{l}\text { Леткі органічні } \\
\text { сполуки }\end{array}$ & $>0,05$ & $>0,05$ & $>0,05$ & $>0,05$ & $>0,05$ & $>0,05$ & $>0,05$ & $>0,05$ & $>0,05$ \\
\hline $\begin{array}{l}\text { Седативні та } \\
\text { снодійні засоби }\end{array}$ & $>0,05$ & $>0,05$ & $<0,01$ & $>0,05$ & $<0,05$ & $<0,01$ & $>0,05$ & $<0,01$ & $<0,01$ \\
\hline Психостимулятори & $>0,05$ & $>0,05$ & $>0,05$ & $>0,05$ & $>0,05$ & $>0,05$ & $>0,05$ & $>0,05$ & $<0,05$ \\
\hline Опіати & $>0,05$ & $>0,05$ & $>0,05$ & $>0,05$ & $>0,05$ & $>0,05$ & $>0,05$ & $>0,05$ & $>0,05$ \\
\hline Психоделічні засоби & $>0,05$ & $>0,05$ & $>0,05$ & $>0,05$ & $>0,05$ & $>0,05$ & $>0,05$ & $>0,05$ & $>0,05$ \\
\hline
\end{tabular}

Аналіз кореляційних зв'язків між вираженням АЗ та напруженістю аддиктивного статусу щодо інших об'єктів залежності за результатами непараметричного кореляційного аналізу довів таке (рис. 1): найбільш тісно АЗ виявилась пов'язаною з тютюнокурінням $\left(r_{s}=0,760\right)$, комп'ютерними іграми $\left(r_{s}=0,703\right)$ - для цих аддиктивних об'єктів коефіцієнт рангової кореляції перевищував 0,7, що інтерпретувалося нами як сильний прямий кореляційний зв'язок. Менш тісний, на рівні помірного (коефіцієнт кореляції в межах 0,3-0,7), прямий кореляційний зв'язок було виявлено між алкоголізацією та вживанням кави або чаю $\left(r_{s}=0,657\right)$, переїданням $\left(r_{s}=0,656\right)$, читанням $\left(r_{s}=0,447\right)$, вживанням седативних та снодійних засобів $\left(r_{s}=0,423\right)$, вживанням психостимуляторів $\left(r_{s}=0,411\right)$, вживанням канабіноїдів $\left(r_{s}=0,370\right)$ та азартними іграми $\left(r_{s}=0,354\right)$. Слабкий прямий кореляційний зв'язок (коефіцієнт кореляції менше 0,3) було виявлено з шопінгом $\left(r_{s}=0,292\right)$ та роботою або навчанням $\left(r_{s}=0,216\right)$. Обернений слабкий кореляційний зв'язок виявлено між вираженням алкоголізації та переглядом телевізійних програм ( $\left.r_{s}=-0,243\right)$ і заняттям спор$\operatorname{Tом}\left(r_{\mathrm{S}}=-0,119\right)$.

У результаті дослідження особливостей афективного статусу хворих на АЗ було виявлено тенденцію до збільшення показників депресії і тривоги з наростанням тяжкості психосоціального стресу; при цьому чинник участі в бойових діях та вимушеного переселення мали другорядне значення.

Так, середні показники депресії (рис. 2) у групі обстежених із легким рівнем психосоціального стресу в комбатантів, вимушених переселенців та місцевих жителів значуще не відрізнялися ( $>>0,05)$, хоча у комбатантів цей показник був найвищим $((6,50 \pm 0,71)$ бала), у вимушених переселенців дещо меншим $((5,33 \pm 3,50)$ бала), а в місцевих жителів - найнижчим $((4,79 \pm 2,55)$ бала).

У групі з помірним психосоціальним стресом зазначені закономірності зберігалися: найбільш високі показники виявлено в комбатантів ((13,07士 $3,86)$ бала), дещо менші - у вимушених переселенців $((12,73 \pm 3,55)$ бала), найнижчі - у місцевих жителів $((9,52 \pm 3,87)$ бала); значущі розбіжності було виявлено при порівнянні груп комбатантів із місцевими жителями і вимушених переселенців із місцевими жителями $(p<0,01)$.

Аналогічно, в осіб із ознаками тяжкого психосоціального стресу серед комбатантів середній показник депресії склав $(17,20 \pm 2,50)$ бала, у вимушених переселенців - $(16,81 \pm 3,31)$ бала, у місцевих мешканців - $(16,27 \pm 3,11)$ бала. При цьому показники депресії значуще відрізнялися при порівнянні між собою груп із різним рівнем психосоціального стресу всередині груп комбатантів, вимушених переселенців та місцевих мешканців. 
Огляди літератури, оригінальні дослідження, погляд на проблему, ювілеї

Схожі закономірності виявлено й для тривоги (рис. 3): вираження і варіативність патологічних тривожних проявів значно більшою мірою залежали від рівня психосоціального стресу, ніж від належності до певної соціальної групи. В цілому, в групах помірного та тяжкого стресу комбатанти виявили вищі рівні тривоги (відповідно $(13,45 \pm 2,34)$ бала та $(22,76 \pm 4,98)$ бала), ніж вимушені переселенці (відповідно (13,27士 $1,98)$ бала та $(21,86 \pm 4,48)$ бала) та місцеві мешканці (відповідно $(11,91 \pm 1,31)$ бала та $(20,63 \pm$ 3,07) бала).

У групі з легким рівнем психосоціального стресу найвищі показники тривоги виявлено у вимушених переселенців $((7,11 \pm 1,27)$ бала), дещо нижчі - у комбатантів $((6,50 \pm 0,71)$ бала) і найнижчі - у місцевих мешканців $((6,08 \pm 2,43)$ бала). При цьому показники тривоги у комбатантів, переселенців та місцевих мешканців у межах кожної з груп (легкий, помірний та тяжкий психосоціальний стрес) значуще не відрізнялися ( $>0,05)$, за винятком порівняння груп комбатантів і переселенців із помірним стресом з відповідною групою місцевих мешканців $(p<0,01$ та $p<0,05)$ і комбатантів та місцевих мешканців із тяжким стресом $(p<0,05) ;$ а при порівнянні комбатантів, переселенців та місцевих мешканців із різними рівнями стресу - статистично значущі ( $p<0,05$ і менше).
При аналізі показників психічної тривоги виявлені закономірності зберігалися: найбільші показники психічної тривоги виявлено у комбатантів (з легким рівнем психосоціального стресу - $(4,50 \pm$ $0,71)$ бала, помірним - $(8,34 \pm 3,07)$ бала, з тяжким $14,82 \pm 3,88$ бала), дещо менші-у вимушених переселенців (відповідно $(3,56 \pm 2,13),(7,77 \pm 2,51)$ та $(14,16 \pm$ $3,99)$ бала), а найменші - у місцевих мешканців (відповідно $(2,08 \pm 1,82),(6,24 \pm 2,49)$ та $(12,90 \pm 3,67)$ бала).

Натомість, показники соматичної тривоги в групах легкого та помірного стресу були найвищими у вимушених переселенців (відповідно $(3,56 \pm 1,94)$ та $(5,41 \pm 2,20)$ бала), дещо меншими -у комбатантів (відповідно $(2,00 \pm 0,00)$ та $(4,90 \pm$ $2,45)$ бала), а найменшими - у місцевих мешканців (відповідно $(4,00 \pm 1,91)$ та $(5,67 \pm 2,23)$ бала). У групі з тяжким психосоціальним стресом найвищі показники соматичної тривоги було виявлено у комбатантів $((7,76 \pm 3,41)$ бала), дещо менші - у вимушених переселенців $((7,53 \pm 3,63)$ бала), а найменші - у місцевих мешканців $((7,42 \pm 3,43)$ бала). При цьому розбіжності у показниках при порівнянні комбатантів, переселенців та місцевих у межах кожної з груп (легкого, помірного та тяжкого стресу) виявились статистично незначущими $(p>0,05)$, а при порівнянні однорідних соціальних груп із різним рівнем психосоціального стресу статистично значущими ( $p<0,05$ і менше).

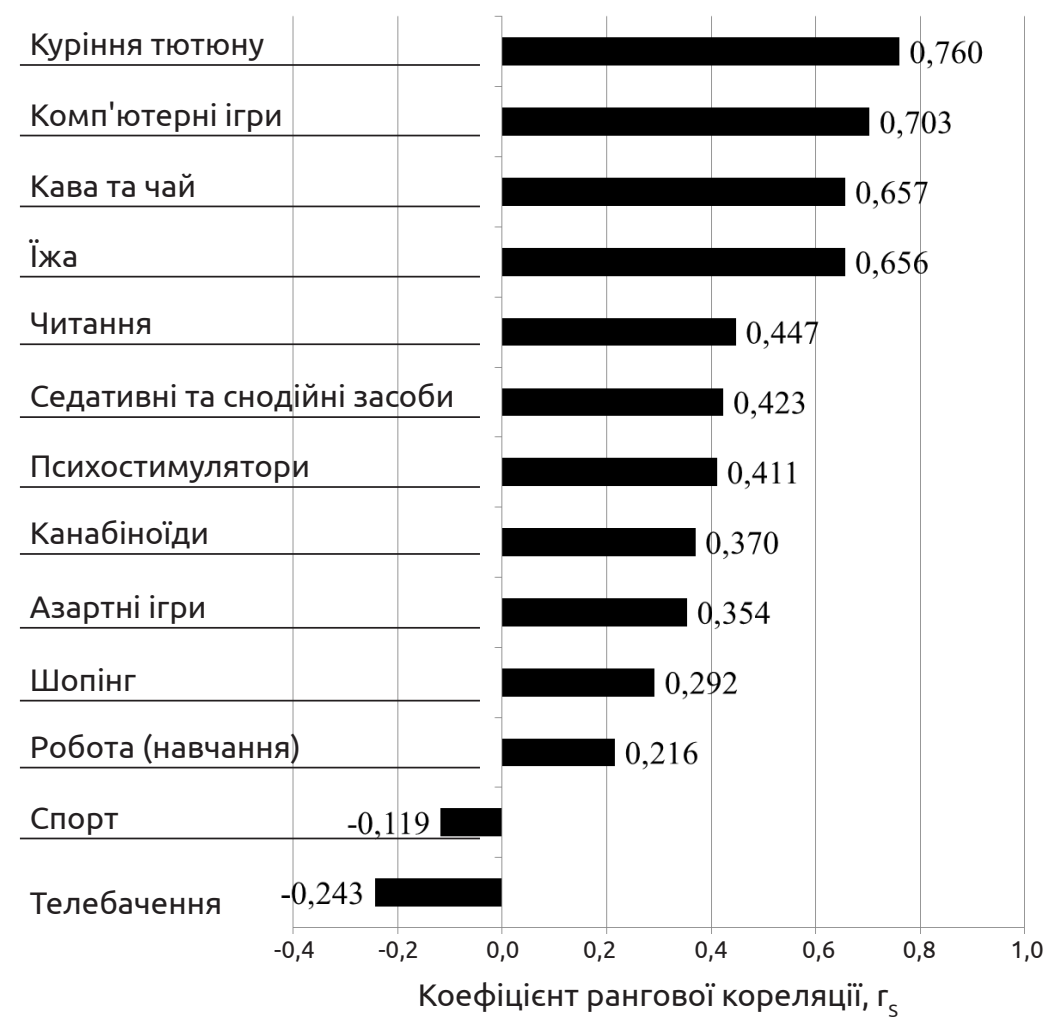

Рис. 1. Кореляційні зв'язки між вираженням АЗ та іншими аддиктивними об'єктами (наведено значущі $(p<0,05)$ коефіцієнти рангової кореляції Спірмена). 
Огляди літератури, оригінальні дослідження, погляд на проблему, ювілеї

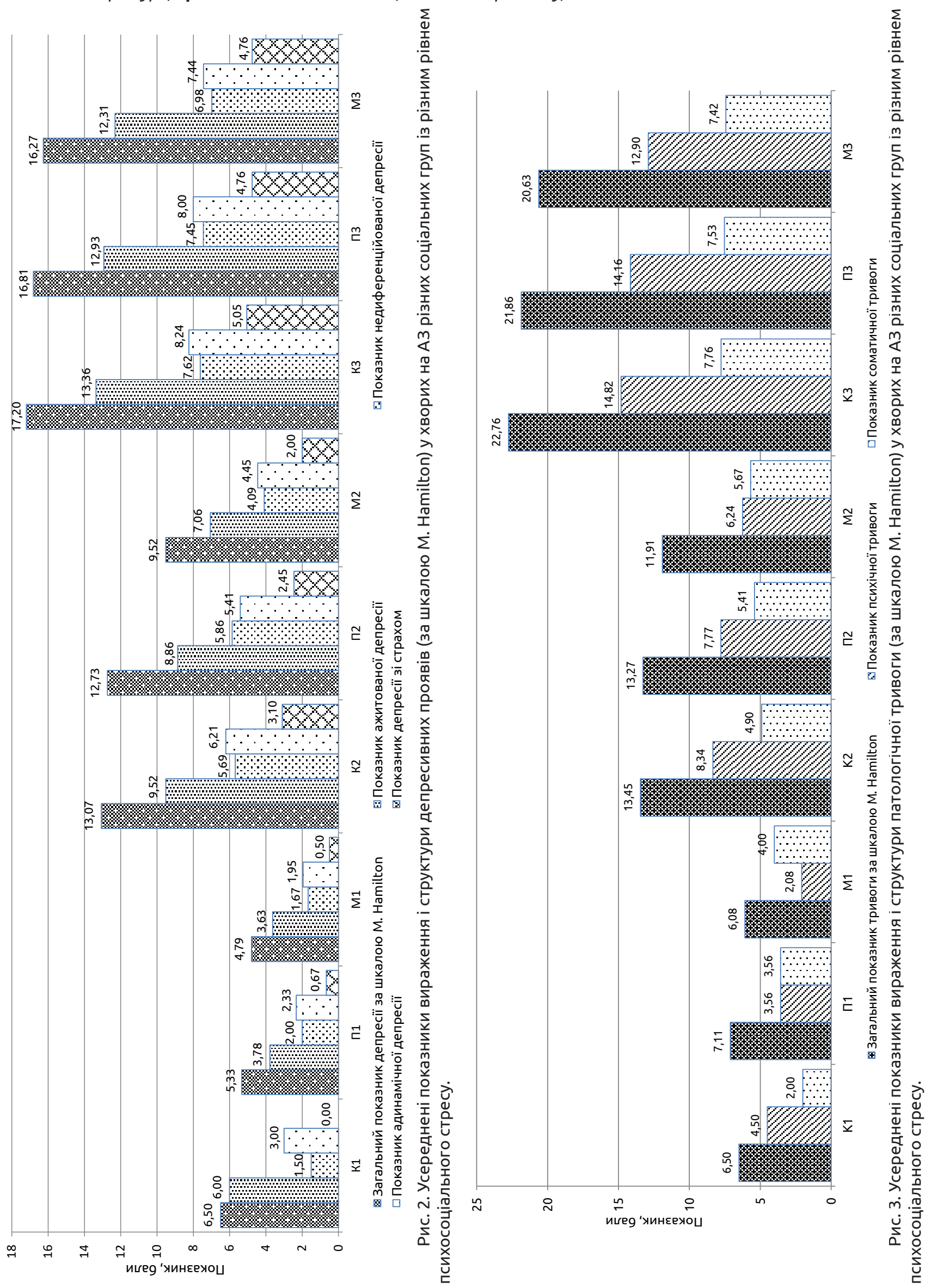


Огляди літератури, оригінальні дослідження, погляд на проблему, ювілеї

Аналіз кореляційних зв'язків між вираженням АЗ та показниками афективного статусу, насамперед вираженням патологічних тривожних і депресивних феноменів за результатами однофакторного непараметричного кореляційного аналізу, продемонстрував таке (рис. 4, 5).

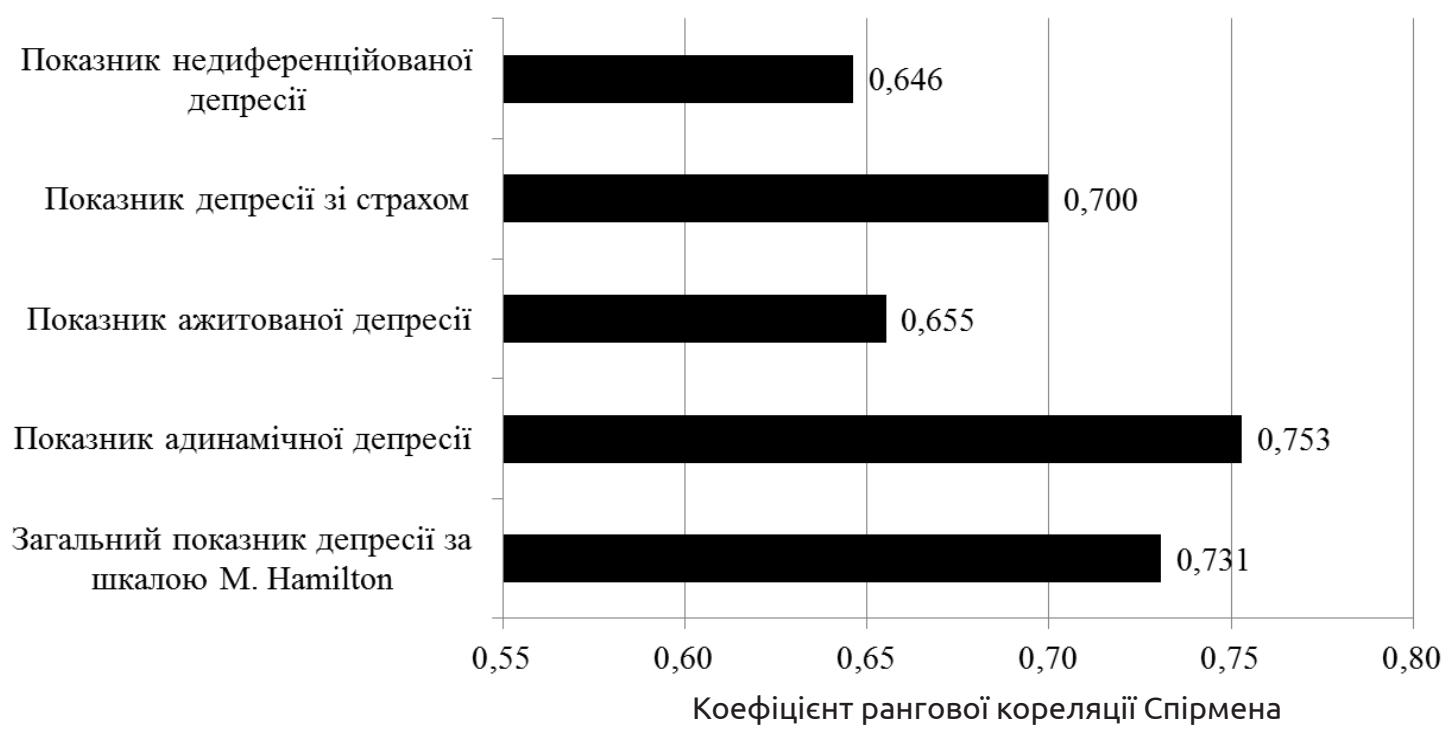

Рис. 4. Кореляційні зв'язки між вираженням АЗ та провідних депресивних феноменів (наведено значущі $(p<0,01)$ коефіцієнти рангової кореляції Спірмена).

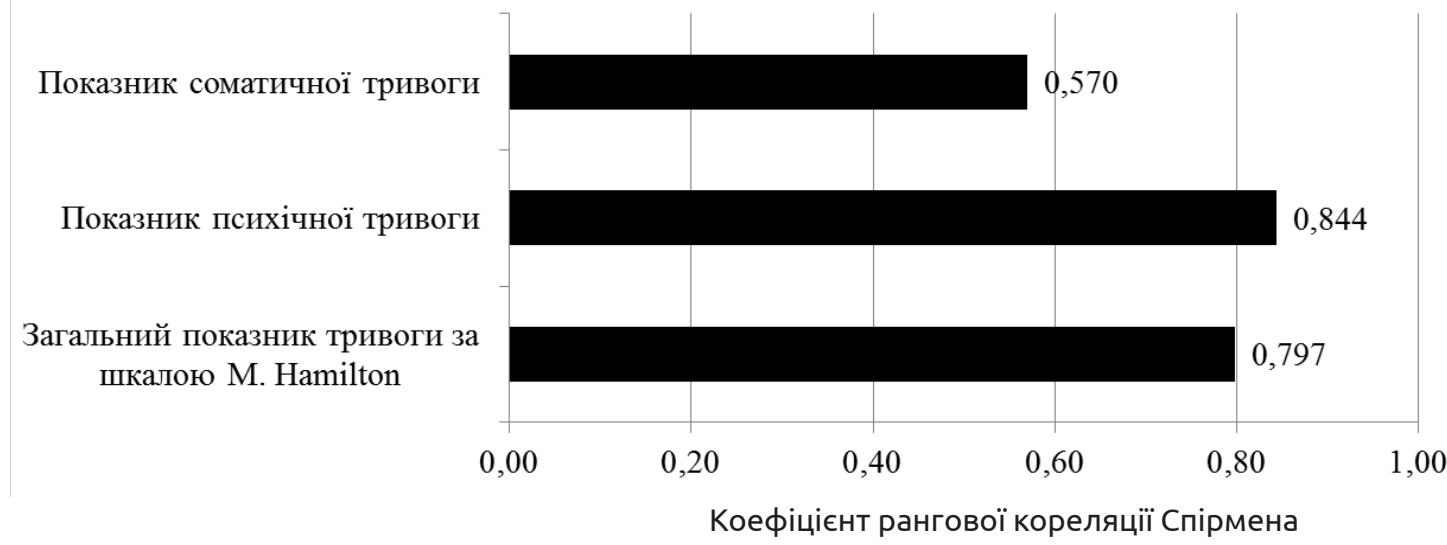

Рис. 5. Кореляційні зв'язки між вираженням АЗ та провідних феноменів патологічної тривоги (наведено значущі $(p<0,01)$ коефіцієнти рангової кореляції Спірмена).

При порівняльному аналізі тісноти кореляційних зв'язків між АЗ та провідними психопатологічними асоційованими 3 нею феноменами більш вагомі взаємозв'язки встановлено між вираженням АЗ та патологічної тривоги $\left(r_{\mathrm{s}}=0,797\right)$, ніж між АЗ і депресивними проявами $\left(r_{s}=0,731\right)$ (хоча і він був на рівні тісного). Ці результати $є$ цілком логічними, бо існування патологічного кола потенціюючих взаємозв'язків «стрес-тривогавживання алкоголю-тривога-стрес-вживання алкоголю" доведено на рівні сучасних досліджень епігенетики: наприклад, ферменти, відповідальні за ремоделювання хроматину (тобто, гістонові деацетилази і метилтрансферази, ДНК-метилтрансферази), були ідентифіковані як загальні молеку- лярні механізми для взаємодії стресу й алкоголю, і на сьогодні розглядаються як перспективні терапевтичні мішені для лікування або запобігання АЗ та асоційованих з нею емоційних розладів [16-19].

Відповідно, найтісніший кореляційний зв'язок, що свідчив про сильну пряму взаємодію двох феноменів, виявлено між вираженням АЗ і психічної тривоги $\left(r_{s}=0,844\right)$, тоді як для соматичної тривоги він виявився найнижчим з усіх встановлених показників, що характеризували афективний статус обстежених ( $r_{s}=0,570$, помірний кореляційний зв'язок). Коефіцієнти кореляції між вираженням АЗ і проявами адинамічної депресії $\left(r_{s}=0,753\right)$ або депресії зі страхом $\left(r_{s}=0,700\right)$ свідчили про наявність тісного прямого зв'язку, а з про- 
Огляди літератури, оригінальні дослідження, погляд на проблему, ювілеї

явами ажитованої $\left(r_{s}=0,655\right)$ та недиференційованої депресії ( $\left.r_{s}=0,646\right)$ - помірного зв'язку.

Висновки. 1. Вираження і клінічна варіативність розладів, пов'язаних зі вживанням алкоголю, асоційована з вираженням психосоціального стресу, який відчувають хворі: зі збільшенням дезадаптивного стресового навантаження відбувається потяжчання клінічної симптоматики АЗ.

2. У пацієнтів із АЗ встановлено схильність до аддиктивної реалізації за деякими об'єктами хімічного та/або нехімічного походження, яка в більшості випадків доходить до рівня вживання зі шкідливими наслідками (нехімічні аддикції) або залежності/небезпечного вживання (хімічні аддикції).

3. Аддиктивний статус хворих на АЗ демонструє напруженість за низкою аддиктивних об'єктів хімічного і нехімічного походження, вираження якої прямо або обернено асоційоване $з$ вираженням АЗ та психосоціального стресу. Серед об'єктів хімічного походження (крім алкоголю), прямий кореляційний зв'язок встановлено для тютюну, психостимуляторів і кави/чаю, нехімічного походження - комп'ютерних ігор, а обернений зв'язок - для таких об'єктів нехімічної аддикції, як спорт і секс.

4. Вираження тютюнокуріння $\left(r_{s}=0,760\right)$ i схильності до надмірного захоплення комп'ютер- ними іграми $\left(r_{s}=0,703\right)$ найбільш тісно пов'язано 3 вираженням АЗ і психосоціального стресу, ніж аддиктивна напруженість за іншими аддиктивними об'єктами.

5. Вираження афективних (депресивних і тривожних) феноменів у хворих на АЗ також виявилось резонансним до динаміки вираження психосоціального стресу: зі збільшенням рівня психосоціального стресу спостерігали зростання тяжкості депресивних і тривожних проявів.

6. Найбільш виражений прямий кореляційний зв'язок встановлено між тяжкістю АЗ та психосоціального стресу і психічною тривогою $\left(r_{s}=0,844\right)$ як складовою клінічної картини афективних розладів, притаманних обстеженим, хоча тіснота кореляційних зв'язків з вираженням як проявів патологічної тривоги, так і депресії, була на рівні високої в обох випадках $\left(r_{s}=0,797\right.$ і $r_{s}=0,731$ відповідно).

Перспективи подальших досліджень. Створення системи таргетно персоніфікованих лікувально-реабілітаційних і профілактичних заходів, диференційованих залежно від рівня патологічного стресового навантаження, випробовуваного пацієнтами, і впровадження її в існуючу комплексну систему надання спеціалізованої медичної допомоги хворим на АЗ.

\section{ЛІТЕРАТУРА}

1. The global burden of disease attributable to alcohol and drug use in 195 countries and territories, 19902016: a systematic analysis for the Global Burden of Disease Study 2016 / L. Degenhardt, F. Charlson, A. Ferrari [et al.] // Lancet Psychiatry. - 2018. pii: S2215-0366(18)303377. doi: 10.1016/S2215-0366(18)30337-7.

2. Life course socioeconomic position, alcohol drinking patterns in midlife, and cardiovascular mortality: Analysis of Norwegian population-based health surveys / E. Degerud, I. Ariansen, E. Ystrom [et al.] // PLOS. - 2018. https://doi.org/10.1371/journal.pmed.1002476

3. Jones L. (2016). Understanding the relationship between poverty and alcohol misuse / L. Jones, H. Sumnall. Centre for Public Health, Faculty of Education, Health and Community, Liverpool John Moores University, Henry Cotton Campus.

4. Palmisano M. Epigenetic mechanisms of alcoholism and stress-related disorders / M. Palmisano, S. C. Pandey // Alcohol. - 2017. - Vol. 60. - P. 7-18.

5. Гапонов К. Д. До проблеми патологічного взаємозв'язку посттравматичних стресових розладів та алкогольної залежності / К. Д. Гапонов // Український вісник психоневрології. - 2015. - Т. 23, вип. 3 (84). C. $120-121$.

6. Карманное руководство к МКБ-10: Классификация психических и поведенческих расстройств (с глоссарием и исследовательскими диагностическими кри-

териями) / сост. Дж. Э. Купер ; под ред. Дж. Э. Купера ; пер. с анг. Д. Полтавца. - К. : Сфера, 2000. - 416 с.

7. AUDIT. Alcohol use disorders identification test / Th. F. Babor, J. C. Higgins-Biddle, J. B. Saunders, M. G. Monteiro // WHO/MSD/MSB/01.6a Original: English Distribution: General. - 2001. -28 p.

8. Stockwell T. The measurement of alcohol dependence and impaired control in community samples / T. Stockwell, T. Sithavan, D. McGrath // Addiction. - 1994. - Vol. 89. P. 167-174.

9. Спосіб діагностики клінічної специфіки і прогнозу перебігу алкогольної залежності у осіб з різним психотравматичним досвідом і рівнем психосоціального стресу / К. Д. Гапонов, І. К. Сосін, О. Ю. Гончарова, М. В. Маркова // Інформаційний лист МОЗ України № 249-2018. - 4 с.

10. Водопьянова Н. Е. Психодиагностика стресса / Н. Е. Водопьянова. - СПб. : Питер, 2009. - 336 с.

11. Метод комплексной оценки аддиктивного статуса индивида и популяции с помощью системы AUDITподобных тестов / И. В. Линский, А. И. Минко, А. Ф. Артемчук [и др.] // Вісник психіатрії та психофармакотерапіï. - 2009. - № 2 (16). - С. 56-70.

12. Маркова М. В. Тест для виявлення розладів, пов'язаних з захопленістю спортом (фітнесом) SPORTUDIT (версія «самозвіт») для непрофесіоналів/М. В. Маркова, М. В. Савіна // Свідоцтво про реєстрацію авторського права на твір № 70682 від 24.02.2017 р. 
Огляди літератури, оригінальні дослідження, погляд на проблему, ювілеї

13. Подкорытов В. С. Депрессии (Современная терапия) / В. С. Подкорытов, Ю. Ю. Чайка. - Х. : Торнадо, 2003. $-350 \mathrm{C}$.

14. Гапонов К. Д. Особливості клінічного аранжування алкогольної залежності у осіб з різним рівнем психосоціального стресу / К. Д. Гапонов // Психіатрія, неврологія, медична психологія. - 2018. - Т. 5, № 9. - С. 41-52.

15. Линский И. В. Аддиктивный статус больных, зависимых от алкоголя / И. В. Линский, О. В. Выглазова // Український вісник психоневрології. - 2014. - Т. 22, вип. 1 (78). - С. 107-113.

16. Becker H. C. Effects of alcohol dependence and withdrawal on stress responsiveness and alcohol consump- tion / H. C. Becker // Alcohol Research. -2012. - Vol. 34 (4). P. 448-458.

17. Koob G. F. The dark side of emotion: the addiction perspective / G. F. Koob // European Journal of Pharmacology. - 2015. - Vol. 753. - P. 73-87.

18. Shorter D. Pharmacologial management of comorbid post-traumatic stress disorder and addictions / D. Shorter, J. Hsieh, T. R. Kosten // American Journal of Addiction. - 2015. - Vol. 24 (8). - P. 705-712.

19. Cadet J. L. Epigenetics of stress, addiction, and resilience: therapeutic implications / J. L. Cadet // Molecular Neurobiology. - 2016. - Vol. 53 (1). - P. 545-560.

\section{REFERENCES}

1. Degenhardt, L., Charlson, F., Ferrari, A., Santomauro, D., Erskine, H., Mantilla-Herrara, A., ... \& Vos, T. (2018). The global burden of disease attributable to alcohol and drug use in 195 countries and territories, 1990-2016: a systematic analysis for the Global Burden of Disease Study 2016. Lancet Psychiatry. Nov 1. pii: S2215-0366(18)30337-7. doi: 10.1016/S2215-0366(18)30337-7.

2. Degerud, E., Ariansen, I., Ystrom, E., Graff-Iversen, S., Høiseth, G., Mørland, J., ... \& Næss, Ø. (2018). Life course socioeconomic position, alcohol drinking patterns in midlife, and cardiovascular mortality: Analysis of Norwegian population-based health surveys. PLOS. https://doi.org/10.1371/journal.pmed.1002476

3. Jones, L., \& Sumnall, H. (2016). Understanding the relationship between poverty and alcohol misuse. Centre for Public Health, Faculty of Education, Health and Community, Liverpool John Moores University, Henry Cotton Campus.

4. Palmisano, M., \& Pandey, S.C. (2017). Epigenetic mechanisms of alcoholism and stress-related disorders. Alcohol, 60, 7-18.

5. Haponov, K.D. (2015). Do problemy patolohichnoho vzaiemozviazku posttravmatychnykh stresovykh rozladiv ta alkoholnoi zalezhnosti [On the problem of the pathological relationship of post-traumatic stress disorders and alcohol dependence]. Ukrainskyi visnyk psykhonevrolohii Ukrainian Bulletin of Psychoneurology, 23, 3 (84), 120-121 [in Ukrainian].

6. Kuper, Dzh.E. (Ed.) (2000). Karmannoe rukovodstvo k MKB-10: Klassifikatsiya psikhicheskikh i povedencheskikh rasstroystv (s glossaryem i issledovatelskimi diagnostycheskimi kriteriyami) [Pocket Guide to ICD-10: Classification of mental and behavioral disorders (with a glossary and research diagnostic criteria)]. Kuper, Dzh.E. (Comp.). Transl. from English by D. Poltavets. Kyiv: Sfera [in Russian].

7. Babor, Th.F., Higgins-Biddle, J.C., Saunders, J.B., \& Monteiro, M.G. (2001). AUDIT. Alcohol Use Disorders Identification Test. WHO/MSD/MSB/01.6a Original: English Distribution: General, p. 28.

8. Stockwell, T., Sithavan, T., \& McGrath, D. (1994). The measurement of alcohol dependence and impaired control in community samples. Addiction, 89, 167-174.

9. Haponov, K.D., Sosin, I.K., Honcharova, O.Yu., \& Markova, M.V. (2018). Sposib diahnostyky klinichnoi spetsyfiky i prohnozu perebihu alkoholnoi zalezhnosti u osib z riznym psykhotravmatychnym dosvidom i rivnem psykhosotsial-

noho stresu [Method of diagnostics of clinical specificity and prognosis of alcohol dependence in people with different psychotraumatic experiences and levels of psychosocial stress]. Informatsiinyi lyst MOZ Ukrainy - Information letter of the Ministry of Health Ukraine, No. 249-2018, p. 4 [in Ukrainian].

10. Vodopyanova, N.E. (2009). Psykhodiagnostika stressa [Psychological diagnosis of stress]. Saint-Petersburg: Piter [in Russian].

11. Lynskiy, I.V., Minko, A.I., Artemchuk, A.F., Grynevych, E.G., \& Markova, M.V. (2009). Metod kompleksnoy otsenki addyktyvnogo statusa individa i populyatsii s pomoshchyu sistemy AUDIT-podobnykh testov [The method of comprehensive assessment of the addictive status of an individual and the population using the system of AUDITlike tests]. Visnyk psykhiatrii ta psykhofarmakoterapii-Bulletin of Psychiatry and Psychopharmacotherapy, 2 (16), 5670 [in Ukrainian].

12. Markova, M.V., \& Savina, M.V. (2017). Test dlia vyiavlennia rozladiv, poviazanykh z zaxoplenistiu sportom (fitnesom) SPORT-UDIT (versiia "samozvit") dlia neprofesionaliv [Test for the detection of disorders associated with sports sport (fitness) SPORT-UDIT (version "self-report") for nonprofessionals]. Svidotstvo pro reiestratsiiu avtorskoho prava na tvir № 70682 vid 24.02.2017 - Certificate of registration of copyright rights to the work No. 70682 from 02/24/2017 [in Ukrainian].

13. Podkorytov, V.S., \& Chayka, Yu.Yu. (2003). Depressii (Sovremennaya terapiya) [Depression. Modern therapy]. Kharkiv: Tornado [in Russian].

14. Haponov, K.D. (2018). Osoblyvosti klinichnoho aranzhuvannia alkoholnoi zalezhnosti u osib z riznym rivnem psykhosotsialnoho stresu [Features of clinical arrangement of alcohol dependence in people with different levels of psychosocial stress]. Psykhiatriia, nevrolohiia, medychna psykholohiia - Psychiatry, Neurology, Medical Psychology, 5, 9, 41-52 [in Ukrainian].

15. Lynskiy, I.V., \& Vyglazova, O.V. (2014). Addiktyvnyy status bolnykh, zavisimykh ot alkogolya [Addictive status of patients dependent on alcohol]. Ukrainskyi visnyk psykhonevrolohii - Ukrainian Herald of Psychoneurology, 22, 1 (78), 107-113 [in Ukrainian].

16. Becker, H.C. (2012). Effects of alcohol dependence and withdrawal on stress responsiveness and alcohol consumption. Alcohol Research, 34 (4), 448-458. 
Огляди літератури, оригінальні дослідження, погляд на проблему, ювілеї

17. Koob, G.F. (2015). The dark side of emotion: the addiction perspective. European Journal of Pharmacology, 753, 73-87.

18. Shorter, D., Hsieh, J., \& Kosten, T.R. (2015). stress disorder and addictions. American Journal of Addiction, 24 (8), 705-712.

19. Cadet, J.L. (2016). Epigenetics of stress, addiction, Pharmacologial management of co-morbid post-traumatic and resilience: therapeutic implications. Molecular Neurobiology, 53 (1), 545-560.

\title{
ОСОБЕННОСТИ АДДИКТИВНЫХ И АФФЕКТИВНЫХ СОСТОЯНИЙ, АССОЦИИРОВАННЫХ С РАССТРОЙСТВАМИ, СВЯЗАННЫМИ С УПОТРЕБЛЕНИЕМ АЛКОГОЛЯ, У БОЛЬНЫХ С РАЗНЫМ УРОВНЕМ ПСИХОСОЦИАЛЬНОГО СТРЕССА
}

\author{
○К. Д. Гапонов
}

\author{
Харьковская медицинская академия последипломного образования
}

РЕЗЮМЕ. 4,2 \% украинцев испытывают проблемы, связанные с употреблением алкоголя, что существенно больше, чем в большинстве развитых стран. Это связано со значительным повышением стрессовой нагрузки, в условиях которой живет сейчас население Украины, что порождает рост уровня употребления алкоголя.

Цель исследования - изучение особенностей выраженности и проявлений аддиктивных и аффективных состояний, ассоциированных с расстройствами, связанными с употреблением алкоголя, у больных с различным уровнем психосоциального стресса.

Материал и методы. В течение 2014-2018 гг. обследовано 312 мужчин, больных алкогольной зависимостью (АЗ): 107 комбатантов, которые имели опыт участия в боевых действиях на Востоке Украины в качестве участников Антитеррористической операции и Операции объединенных сил; 89 вынужденно перемещенных лиц с временно оккупированных районов Донецкой и Луганской областей; 116 человек - жителей г. Харькова и Харьковской области, которые не были комбатантами или вынужденно перемещенными лицами. Исследование включало использование клинического, клинико-психопатологического, психодиагностического и статистического методов.

Результаты. Установлено, что выраженность и клиническая вариативность расстройств, связанных с употреблением алкоголя, ассоциированы с выраженностью психосоциального стресса, который испытывают больные: с увеличением дезадаптивной стрессовой нагрузки происходит утяжеление клинической симптоматики АЗ.

Аддиктивный статус больных АЗ демонстрирует напряженность по ряду аддиктивных объектов химического и нехимического происхождения, выраженность которой прямо или обратно ассоциирована с выраженностью АЗ и психосоциального стресса. Среди объектов химического происхождения (кроме алкоголя), прямая корреляционная связь установлена для табака, психостимуляторов и кофе/чая, нехимического происхождения - компьютерных игр, а обратная связь - для таких объектов нехимической аддикции, как спорт и секс. Выраженность куре-

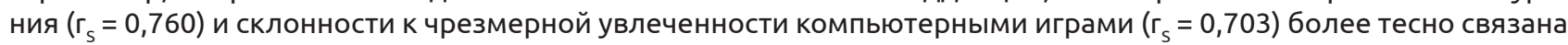
с выраженностью АЗ и психосоциального стресса, чем аддиктивная напряженность по другим аддиктивным объектам.

Выраженность аффективных феноменов у больных АЗ также оказалась конгруэнтной к динамике выраженности психосоциального стресса: с увеличением уровня психосоциального стресса наблюдался рост тяжести депрессивных и тревожных проявлений. Наиболее выраженная прямая корреляционная связь установлена между тяжестью АЗ, психосоциального стресса и психической тревогой $\left(r_{s}=0,844\right)$, как составляющей клинической картины аффективных расстройств, присущих обследованным, хотя теснота корреляционных связей с выраженностью как проявлений патологической тревоги, так и депрессии, была на уровне высокой в обоих случаях ( $r_{\mathrm{s}}=0,797$ и $\mathrm{r}_{\mathrm{s}}=0,731$ соответственно).

Выводы. Перспективой дальнейших исследований является создание системы таргетных персонифицированных лечебно-реабилитационных и профилактических мероприятий, дифференцированных в зависимости от уровня патологической стрессовой нагрузки, испытываемой пациентами, и внедрение ее в существующую комплексную систему оказания специализированной медицинской помощи больным АЗ.

КЛЮЧЕВЫЕ СЛОВА: алкогольная зависимость; психосоциальный стресс; аддиктивный статус; аффективные расстройства; депрессия; тревога. 


\title{
Огляди літератури, оригінальні дослідження, погляд на проблему, ювілеї \\ FEATURES OF ADDICTIVE AND AFFECTIVE STATES ASSOCIATED WITH DISORDERS RELATED TO ALCOHOL CONSUMPTION, IN PATIENTS WITH DIFFERENT LEVELS OF PSYCHOSOCIAL STRESS
}

@K. D. Gaponov

\author{
Kharkiv Medical Academy of Post-graduate Education
}

SUMMARY. Introduction. $4.2 \%$ of Ukrainians have alcohol-related problems, which is significantly higher than in most developed European countries. This is due to a significant increase in the long-term stress load, which the population of Ukraine has now, which generates an increase in the level of alcohol consumption.

The aim of the study - to learn the peculiarities of severity and manifestations of addictive and affective states associated with alcohol-related disorders in patients with different levels of psychosocial stress.

Material and Methods. The study was carried out on the basis of the Municipal Non-Commercial Enterprise of Kharkiv Regional Council "Regional Narcological Dispensary" during the period from 2014 to 2018, where upon condition of informed consent, being committed to the principle of bio-ethics and deontology, 312 men with alcohol dependence were examined: 107 combatants who had the experience of engaging in military actions on the East of Ukraine as participants in the Anti-Terrorist Operation and Operation of the Joint Forces; 89 forcibly displaced persons from temporarily occupied districts of Donetsk and Luhansk region; and 116 residents of the city of Kharkiv and Kharkiv region who were not combatants or forcibly displaced persons. The study included the use of clinical, clinical-psychopathological, psychodiagnostic and statistical methods.

Results. It is established that the severity and clinical variability of alcohol-related disorders are associated with the severity of psychosocial stress experienced by the patients: with an increase in the maladaptive stress load, there is a decline of the clinical symptoms of alcohol dependence.

The addictive status of patients with alcohol dependence demonstrates the tension of a number of addictive objects of chemical and non-chemical origin, the severity of which is directly or inversely associated with the severity of alcohol dependence and psychosocial stress. Among objects of chemical origin (except for alcohol), the direct correlation is established for tobacco, psychostimulants and coffee / tea, and among objects of non-chemical origin - for computer games, and feedback - for such non-chemical objects of addiction as sport and sex. The severity of tobacco smoking $\left(r_{s}=.760\right)$ and the propensity to excessive seizure of computer games $\left(r_{s}=0.703\right)$ is most closely related to the severity of alcohol dependence and psychosocial stress, as well as the addictive tension for other addictive objects.

The severity of affective phenomena in patients with alcohol dependence also turned out to be congruent to the dynamics of the severity of psychosocial stress: with an increase in the level of psychosocial stress, an increase in the severity of depressive and anxiety manifestations was observed. The most severe direct correlation was established between the severity of alcohol dependence and psychosocial stress, and psychological anxiety $\left(r_{s}=0.844\right)$ as a component of the clinical image of affective disorders, which are characteristic for the surveyed, although the tightness of correlations with severity as manifestations of pathological anxiety and depression was at a high level in both cases $\left(r_{\mathrm{s}}=0.779\right.$ and $r_{\mathrm{s}}=0.731$, respectively).

Conclusions. The prospect of further research is the creation of a system of target-personified treatment and rehabilitation and preventive measures, differentiated depending on the level of pathological stress experienced by the patients, and its introduction into the existing integrated system of providing specialized medical care to patients with alcohol dependence.

KEY WORDS: alcohol dependence; psychosocial stress; addictive status; affective disorders; depression; anxiety. 